Article

\title{
Development Initiatives, Micro-Enterprise Performance and Sustainability
}

\author{
Wan Nurulasiah binti Wan Mustapa ${ }^{1}$, Abdullah Al Mamun ${ }^{2, *(\mathbb{D})}$ and \\ Mohamed Dahlan Ibrahim ${ }^{1}$ \\ 1 Faculty of Entrepreneurship and Business, Universiti Malaysia Kelantan, Karung Berkunci 36, \\ Taman Bendahara, 16100 Pengkalan Chepa, Kelantan, Malaysia; \\ xiaojienurulmustapa@gmail.com (W.N.b.W.M.); dahlan@umk.edu.my (M.D.I.) \\ 2 Global Entrepreneurship Research and Innovation Centre (GERIC), Karung Berkunci 36, Taman Bendahara, \\ 16100 Pengkalan Chepa, Kelantan, Malaysia \\ * Correspondence: abdullah.a@umk.edu.my or mamun7793@gmail.com; Tel.: +6-013-300-3630
}

Received: 28 May 2018; Accepted: 22 August 2018; Published: 27 August 2018

\begin{abstract}
Towards improving the socio-economic condition of low-income households, development organizations offer a repertoire of initiatives. This study focused on the impacts of access to working capital and enterprise development training programs, on the performance and sustainability of micro-enterprises owned and managed by low-income households, in the state of Kelantan, Peninsular Malaysia. The data of 450 micro-entrepreneurs, was randomly selected from the participants' list of three development organizations servicing Kelantan: Amanah Ikhtiar Malaysia (AIM); National Entrepreneurs Economic Group Fund (TEKUN); and Malaysia Fisheries Development Board (LKIM). This study revealed several participation indicators (i.e., years of participation, total number of trainings, total number of training hours received, and number of center meetings or discussions attended, etc.), which have a positive effect on micro-enterprise performance and sustainability. However, the findings were inconclusive as one of the key participation indicators, 'total amount of economic loans received', showed a negative (not statistically significant) effect on micro-enterprise performance and sustainability. This study expanded the limited literature on micro-enterprise performance and sustainability, and the role of working capital and enterprise development training programs; thus providing a clearer understanding of the effectiveness of current development initiatives.
\end{abstract}

Keywords: micro-credit; training; low-income households; micro-enterprise performance; micro-enterprise sustainability; Malaysia

JEL Classification: G21; I38

\section{Introduction}

The National Small and Medium Enterprise (SME) Development Council defines micro-enterprises as companies primarily participating in, the manufacturing and agro-based industries, which record annual sales turnover of less than Ringgit Malaysia (RM) 300,000 or less than five full-time employees (Bank Negara Malaysia 2013). In 2016, Malaysia recorded a total of 645,135 SMEs, whereby micro-enterprises made up 76.7 percent $(496,458)$. Kelantanese micro-enterprises made up only 5.1 percent of the total SMEs (DOSM 2016). Micro-enterprise participation is significant in key economic sectors. In the services sector, micro-enterprises make up 79.5 percent of total SMEs, whilst in the manufacturing and agriculture sectors, they make up 57.1 percent and 56.2 percent, respectively. However, micro-enterprise participation recorded less than 50 percent of total SMEs in the construction sector (43.4 percent), 
as well as the mining and quarrying sector (only 19.2 percent as compared to 42.1 percent of small enterprises) (SME Annual Report 2015).

The growth of micro-enterprises is due to factors, such as personal aspirations, commitment, social capital, core functional business activities and growth strategies (Clark and Douglas 2014). However, the challenges of micro-enterprise include: limited access to credit and raw-materials; sluggish demand and in turn customer shortage; insufficient working space; limited access to equipment, such as machines, tools, or spare parts; as well as insufficient access to utilities, such as electricity and goods (Seibel 1996). These challenges might be alleviated through more efficient development initiatives, specifically, access to working capital and enterprise development training programs. Working capital refers to small loans extended to low-income micro-entrepreneurs. Meanwhile, enterprise development training programs are skills-based training aimed at improving micro-entrepreneurs' competencies in money and business management, as well as improving marketing strategies to increase micro-enterprise revenue, and lead to better performance and sustainability. Access to these facilities is considered a building block for sustainable micro-enterprises, and the Malaysian government has established several development organizations to ease accessibility.

During the 1970s and 1980s, three key development organizations were established to provide access to working capital and enterprise development training programs: (i) Amanah Ikhtiar Malaysia (AIM); (ii) National Entrepreneurs Economic Group Fund (TEKUN); and (iii) Malaysia Fisheries Development Board (LKIM). AIM is a private trust established on 17 September 1987 and registered under the Trustees (Incorporation) Act (1952). AIM provides various loans to micro-entrepreneurs. The three economic loans are namely the I-Mesra loan, I-Srikandi loan, and the I-Wibawa loan. Other loans include: the I-Penyayang loan, which is a recovery loan; the I-Bestari loan, which is an education loan; and the housing/multipurpose loan known as the I-Sejahtera loan. AIM also provides non-financial assistance programs known as Sahabat Teras, Strengthening Entrepreneurship and Sahabat Berjaya, which focus on improving key competencies and skills, and monitoring of the risk management plan. Another development organization is TEKUN. Established under the Ministry of Entrepreneurial and Cooperative Development in November 1998, TEKUN provides four economic loans namely TEKUN Nasional Financial Scheme, Teman TEKUN Financing Scheme, I-Factoring Financing Scheme, and Ar-Rahnu TEKUN. However, TEKUN only offers one non-financial assistance program, which is the Seminar of Entrepreneurship Fundamentals. This seminar trains new borrowers about the basics of marketing and accounting. Lastly, LKIM is an authorized body under the Ministry of Agriculture and Agro-Based Industry, which was incorporated under Act 49 of the Malaysia Fisheries Development Board Act (1971). LKIM was established to provide small-scale working capital, specifically to the fishing community. LKIM extends various economic and non-economic loans; including the fishermen fund, fishermen success fund, fishermen institutional development financing scheme, commercial fishermen financing scheme, fishermen inboard engine financing scheme, and the coastal fishermen financing scheme (LKIM 2018). LKIM plans, coordinates, manages, and processes these loan facilities to fishermen towards socio-economic development. With this wide range of loan facilities, LKIM monitors project implementation and repayment performance of borrowers. However, the LKIM provides four categories of non-financial assistance programs, which are the fishermen community development, fisheries institutional development, fishermen assistance, and fishermen poverty eradication.

The collective objectives of the development initiatives, are focused on improving micro-enterprise performance and sustainability. Therefore, it was eminent that this study evaluates the effectiveness of micro-credit and training programs, in particular, access to working capital and enterprise development training programs, in achieving income generating outcomes. This study focused on the state of Kelantan, as it is the poorest state in Peninsular Malaysia. In 2017, Kelantan only achieved 0.4 percent of (EPU 2018). 


\section{Literature Review}

\subsection{Theoretical Foundation}

The arguments presented in this study were built on a combination of modern development theory and the theory of human capital. Modern development theory highlights access to working capital, as one of the key factors contributing to overall economic development. Access to working capital provides start-up capital, which enables low-income households to engage in available income-generating opportunities. Therefore, access to working capital can lead to an increase in micro-enterprise income among low-income micro-entrepreneurs. The study by Al-Mamun et al. (2010) mentioned that access to working capital increases the net worth of micro-enterprise assets, which can lead to an increase in micro-enterprise performance.

Human capital is defined as the knowledge and skills that individuals, households, or a generation accumulate through training, formal education, and experience, which facilitate them to improve their socio-economic well-being (Heckman 2000). Human capital theory argues that employee economic performance is mainly based on his/her general and specific human capital, which evolves from his/her investment experience (Streletzki and Schulte 2013). The effects of training and experience from development initiatives to underprivileged micro-entrepreneurs, on micro-enterprise performance is rationalized using the human capital theory. Based on this argument, development organizations provide a repertoire of training programs to low-income micro-entrepreneurs to enhance various skillsets, such as money management, ability to generate more income, and the proper use of credit, so as to impact micro-enterprise performance and sustainability.

\subsection{Impact of Development Initiatives}

Development initiatives refer to the financial and non-financial assistance provided by development organizations towards poverty alleviation, as part of achieving sustainable development goals. The mission of the development organizations is to ensure that financial and non-financial assistance increase the income and assets of individuals, communities, and organizations, thus achieving sustainable growth leading towards the eventual reduction of economic vulnerability and an end to poverty. Internationally, several multilateral institutions were established, such as the United Nations, the World Bank, and a diversity of non-governmental organizations (NGOs) to work together with governments on various delivery platforms to serve development initiatives to targeted cohorts. This includes low-income micro-entrepreneurs. In Malaysia, the government works in partnership with the private sector, NGOs, and the three development organizations-AIM, TEKUN, and LKIM-to deliver development initiatives to the low-income micro-entrepreneur cohort. Since their inception, various financial and non-financial support has been provided to low-income micro-entrepreneurs to increase their income and assets. Consistent with Anderson et al. (2002), these forms of assistance commonly constituted access to working capital and enterprise development training programs.

Development organizations provide working capital and enterprise development training programs as tool to increase the income, assets, performance, and sustainability of low-income micro-entrepreneurs, and to lift them out from poverty (Rosenberg 2010). According to Uotila (2005), increased participation in micro-credit and training programs, increases participants' enterprise income, assets, and level of households' welfare over time. Dunn (2005) also reported similar results, that is participation in micro-credit had significant positive impacts on business investment and business registration. In India, Swain and Varghese (2009) found a positive relationship between micro-credit and livestock accumulation, but no impact on land value or business wealth, and even physical assets. Their study also showed that micro-credit and training programs have a positive effect on the net worth of micro-enterprise assets. However in Pakistan, Montgomery and Weiss (2011) argued that although approximately two-thirds of the total participants received micro-credit for micro-enterprises, there was no significant positive impact on sales or profit from those activities. Therefore, this study intends to measure the impact of access to working capital and enterprise development training programs, 
on micro-enterprise performance and sustainability among participants of various development initiatives in Kelantan.

\subsection{Impact on Micro-Enterprise Performance}

According to the World Bank (2008), access to working capital and enterprise development training programs for micro-entrepreneurs has contributed to economic growth. These two products of development initiatives act as conduits, for growth at firm level. This is because the ease of accessibility of credit and training programs, provide an enabling environment conducive for micro-entrepreneurs to thrive, thus impacting micro-enterprise performance (Adekunle 2011; Danciu 2013). Previous studies on the impact of development initiatives, have established enterprise performance indicators. Sutoro (1990) showed that participation in development initiatives impacted enterprise performance, as indicated by increases in enterprise income by 93 percent, ownership of productive machineries by 26 percent, and ownership of business vehicles at about 16 percent. In India, Panda (2009) noted a significant increase in borrowers' household income at 11.41 percent, and subsequent increase in savings by 42.53 percent. Additionally, there was a higher asset position, scored at 9.75 percent among participants, compared to non-participants. In Malaysia, Al-Mamun et al. (2012) reported that existing and frequent participants of development initiatives, scored a positive relationship between the number of participations per month and key micro-enterprise performance indicators, such as the amount of credit, as well as current market values of assets comprising livestock, agricultural, and production equipment; wherein they scored higher as compared to new participants. In a recent study on Malaysian micro-enterprises owned and managed by micro-entrepreneurs who participated in various development initiatives, Al-Mamun et al. (2018) mentioned that the effect of micro-enterprise performance was expected to uplift the economic wellbeing of low-income households, thus minimizing economic vulnerability. Hence, it is assumed that superior performance, as indicated by increases in income and asset accumulation, may aid micro-enterprises owned and managed by low-income micro-entrepreneurs, to better cope with economic challenges. From the above discussion, this study therefore formulated the following hypotheses:

Hypothesis 1. Access to working capital and enterprise development training programs, leads to improved performance of micro-enterprises owned and managed by participants from low-income households in Kelantan, Malaysia.

\subsection{Impact on Micro-Enterprise Sustainability}

Raderbauer (2011) defined sustainability as a business principle that seeks to fulfill three performance dimensions: environmental, social, and economic sustainability. Environmental sustainability refers to business practices, which utilize natural resources in a way that lasts longer and reduces negative impacts within the environment that the firm operates, for example via waste management. Social sustainability is concerned with business practices that impact the social needs of all the firm's stakeholders, including customers, shareholders, employees, and communities. Finally, economic sustainability refers to business practices that respond to market demands by providing goods and services efficiently and profitability. According to Gualandris et al. (2014), the construct of sustainability remains complex, thus, an effort towards developing indicators at firm level remains a work-in-progress.

The concept of micro-enterprise sustainability is at a nascent stage, amidst growing interest in the last two decades. Micro-enterprise sustainability, involves the application of the three sustainability principles into business operations. Considered as the micro-enterprise success strategy for the future, the renewed focus is not only to provide good and services that meet customers' demands in efficient and profitable ways, but to achieve social equity and environmental preservation as well (Danciu 2013). According to Gualandris et al. (2014), a firm's sustainability performance can be measured using three indicators in a comparative approach. In essence, firms compare their sustainability performance 
against their competitors using the indicators of environmental performance, employee satisfaction, and social reputation. Sustainably designed products and services, as well as supply chain and product life cycles which do not harm the environment, represent environmental performance. Whereas social responsibility is represented by employee satisfaction and social reputation.

Participants of development organizations receiving enterprise development training programs are expected to improve their overall enterprise management skills, which ultimately increases micro-enterprise income, assets, and sustainability (Ssendi and Anderson 2009; Kessy and Temu 2010; Chan and Ghani 2011; Al-Mamun et al. 2011; Ferdousi 2015). Hence, based on the above, the present study puts forward the following hypothesis:

Hypothesis 2. Access to working capital and enterprise development training programs, leads to improved sustainability of micro-enterprises owned and managed by participants from low-income households in Kelantan, Malaysia.

\section{Research Methodology}

This study used a cross-sectional design and collected quantitative data through structured interviews. The sample comprised low-income micro-entrepreneurs who participated in socio-economic development programs in the state of Kelantan, Malaysia. Malaysian development organizations AIM, TEKUN, and LKIM provided a list of 500, 350, and 156 low-income micro-entrepreneurs, respectively. In total, there were 1006 potential respondents from seven districts: Tumpat, Bachok, Pasir Puteh, Pasir Mas, Tanah Merah, Gua Musang, and Jeli. Then the data collection team contacted all the respondents to explain the purpose of the survey. After they agreed to be interviewed, data collection team made appointments with them. Out of 1006 respondents, only 450 (150 from AIM; 150 from TEKUN; and 150 from IKIM) agreed to be interviewed.

\subsection{Sample Size}

The sample size for this study was determined according to Krejcie and Morgan (1970) guidelines formula:

$$
\mathrm{s}=\frac{X^{2} N P(1-P)}{d^{2}(N-1)+X^{2} P(1-P)}
$$

where

$\mathrm{s}=$ required sample size.

$X^{2}=$ the table value of chi-square for 1 degree of freedom at the desired confidence level (3.841).

$N=$ the population size $(88,435)$

$P=$ the population proportion (assumed to be 0.50 )

$d=$ the degree of accuracy expressed as a proportion (0.05).

As the population was 88,435 , a sample size of 383 was required. To minimize possible complications from a small sample size, this study collected data from 450 participants.

\subsection{Research Instruments}

The questionnaire employed in this study was designed using simple and unbiased terms to facilitate respondents' easy understanding of the questions presented to them, and thereafter be able to provide accurate answers based on their own perceptions. Micro-enterprise performance was measured by adopting six items from the study conducted by Muniady et al. (2015). Similarly, Micro-enterprise sustainability was measured by adopting six items from Gualandris et al. (2014) and Raymond et al. (2013). The level of micro-enterprise performance and sustainability was measured using a 7-point Likert scale with; 1: strongly disagree, to 7: strongly agree. To measure the micro-enterprise performance, this study focused on respondent's assessment of their financial performance compared 
to the major competitors; including return on investment, firm return on total sales, employment growth, and overall business performance. As for micro-enterprise sustainability compared to major competitors, this included environmental performance, quality of life provided to employees, employee satisfaction, retention of employees, social reputation, and investment in society. This study used open-ended questions to measure the participation and control variable.

\subsection{Data Analysis}

The data were analyzed by using the Statistical Package for Social Science (SPSS) (IBM, Armonk, NY, USA) in an easy to understand format, for interpretation and tabulation. Multiple regression analysis was performed to establish the relationship between micro-enterprise performance and micro-enterprise sustainability, with participation in development initiatives, among the low-income households in Kelantan, Malaysia. Partial correlation analysis was conducted to determine the relationship linked to controlling the effects of selected antecedents. Finally, this study used multiple regression analysis to assess the effect of participation on performance and sustainability. Typically, the presence of outliers ought to be high in such study genres due to the relatively higher variation in the distribution. Hence, the model was tested for multivariate normality to discard outliers. After that, the model was tested again to verity that the original findings and significances were not significantly affected by the absence of multivariate normality.

\section{Summary of Findings}

\subsection{Demographic Characteristics}

The data were collected from 450 low-income micro-entrepreneurs, located in the state of Kelantan, Malaysia. From the total, 224 respondents (49.8 percent) were males and 226 (50.2 percent) were females. From the 450 respondents, 266 (59.1 percent) were service providers, followed by 80 or 17.8 percent respondents that were retailers. The other 52 (11.6 percent) were manufacturers, and 33 (7.3 percent) were fishermen. Only 17 (3.8 percent) were engaged in livestock activities, whilst 2 or 0.4 percent were engaged in wholesaling as their core business activity. As per the number of years the respondents' enterprises were established, 192 (42.7 percent) were between 6 and 10 years, followed by 144 (32.0 percent) between 11 and 15 years, and then 60 (13.3 percent) were between 16 to 20 years. Whereas 52 or 11.6 percent respondents had enterprises established between 1 and 5 years. Only 2 or 0.4 percent of the respondents had their enterprises established, for more than 21 years. In terms of age, most of the respondents fell between 41 and 50 years ( 200 respondents, or 44.4 percent). The other 125 (27.8 percent) were between 51 and 60 years old, 64 (14.2 percent) were between 31 and 40 years old, and 40 ( 8.9 percent) were 61 years old and above. Only 21 (4.7 percent) respondents, were 30 years old and below. Table 1 shows the demographic profiles of the respondents.

\subsection{Descriptive Analysis}

As presented in Table 2, the mean value for years of participation in development initiatives was 10.87 years, with a standard deviation of 4.43 years. The length of participation is one of the independent variables used in impact studies to examine the effectiveness of development initiatives. This is because the longer they participate in an initiative, the higher the credit one can receive, which in turn could lead to higher micro-enterprise income, thus impacting micro-enterprise performance positively. The mean value for the total amount of economic loans received by participants was RM 21,454.44, with a standard deviation of RM 11,167.23. The higher standard deviation indicated that some micro-entrepreneurs' borrowings were much higher than others. The mean value for the total number of training programs received by participants was 5.50 times, with a standard deviation of 2.77 times. Meanwhile, the mean value for the total number of training hours received by participants was $40.47 \mathrm{~h}$, with a standard deviation of $22.87 \mathrm{~h}$; whilst the total number of center meetings or discussions attended by participants was 32.77 times, with a standard deviation of 20.94 times. 
Table 1. Profile of the Respondent.

\begin{tabular}{|c|c|c|c|c|c|}
\hline & $\mathbf{n}$ & $\%$ & & $\mathbf{n}$ & $\%$ \\
\hline Gender & & & Firm Established & & \\
\hline Male & 224 & 49.8 & 1 to 5 Years & 52 & 11.6 \\
\hline Female & 226 & 50.2 & 6 to 10 Years & 192 & 42.7 \\
\hline \multirow[t]{2}{*}{ Total } & 450 & 100.0 & 11 to 15 Years & 144 & 32.0 \\
\hline & & & 16 to 20 Years & 60 & 13.3 \\
\hline Types of Firm & & & 21 Years and Above & 2 & 0.4 \\
\hline Manufacturing & 52 & 11.6 & Total & 450 & 100.0 \\
\hline Retailing & 80 & 17.8 & & & \\
\hline Service & 266 & 59.1 & Age & & \\
\hline Livestock & 17 & 3.8 & Up to 30 years old & 21 & 4.7 \\
\hline Wholesaling & 2 & 0.4 & 31 years old -40 years old & 64 & 14.2 \\
\hline Fishing & 33 & 7.3 & 41 years old- -50 years old & 200 & 44.4 \\
\hline \multirow[t]{3}{*}{ Total } & 450 & 100.0 & 51 years old-60 years old & 125 & 27.8 \\
\hline & & & 61 years old and above & 40 & 8.9 \\
\hline & & & Total & 450 & 100.0 \\
\hline
\end{tabular}

Source: Author(s) own compilation.

Table 2. Respondents and Participation Details.

\begin{tabular}{ccccc}
\hline & Min. & Max. & Mean & Std. Dev. \\
\hline Number of Years & 1 & 22 & 10.87 & 4.43 \\
Total amount of economic loan received & 1000 & 95,000 & $21,454.44$ & $11,167.23$ \\
Total number of training programs attended & 0 & 16 & 5.50 & 2.77 \\
Total number of training hours & 0 & 180 & 40.47 & 22.87 \\
Number of Centre Meeting or Discussion & 0 & 48 & 32.77 & 20.94 \\
\hline
\end{tabular}

Source: Author(s) own compilation.

\subsection{Control Variables}

As presented in Table 3, the mean value for respondent age was 48.31 years old, with a standard deviation of 9.619 years old. The mean value for education was 5.82 schooling years, with a standard deviation of 3.560 schooling years. Education was considered a control variable because educated households were expected to have the ability to generate more income. As expected, the mean value for the number of gainfully employed member was 2.91 people, with a standard deviation of 1.132 people. The mean value for the number of sources of income was 1.08, with a standard deviation of 0.286 ; whereas the mean value for the number of years the micro-enterprise was established was 10.57 years, with a standard deviation of 4.124 years.

Table 3. Participation Details.

\begin{tabular}{ccccc}
\hline & Minimum & Maximum & Mean & Std. Dev. \\
\hline Respondents Age & 19 & 77 & 48.31 & 9.619 \\
Education & 0 & 15 & 5.82 & 3.560 \\
Number of Gainfully Employed members & 1 & 8 & 2.91 & 1.132 \\
Number of Sources of Income & 1 & 3 & 1.08 & 0.286 \\
Micro-Enterprise Established (Years) & 1 & 23 & 10.57 & 4.124 \\
\hline
\end{tabular}

Source: Author(s) own compilation.

\subsection{Outcome Variables}

As presented in Table 4, micro-enterprise performance was tested using 6 items with Cronbach's alpha of 0.867 , where the value of mean was 3.9779 , with a standard deviation of 0.5295 . Meanwhile, 
micro-enterprise sustainability was tested using 6 items with Cronbach's alpha of 0.798, where the mean value was 4.3112 , with a standard deviation of 0.3718 .

Table 4. Participation Details.

\begin{tabular}{lcccccc}
\hline & Items & CA & Minimum & Maximum & Mean & Std. Dev. \\
\hline Micro-Enterprise Performance & 6 & 0.867 & 1.83 & 5.00 & 3.9779 & 0.5295 \\
Micro-Enterprise Sustainability & 6 & 0.798 & 3.00 & 5.00 & 4.3112 & 0.3718 \\
\hline
\end{tabular}

Note: Cronbach's Alpha (CA). Source: Author(s) own compilation.

\subsection{Participation and Key Determinants}

As presented in Table 5, micro-enterprise performance and micro-enterprise sustainability were grouped, based on years of participation. The $p$-value of the Analysis of Variance (ANOVA) F-test for micro-enterprise performance was 0.491 , which showed that the mean difference of micro-enterprise performance across the groups was not statistically significant. Meanwhile, the $p$-value of ANOVA F-test for micro-enterprise sustainability was 0.002 , which showed that the mean difference in micro-enterprise sustainability was statistically significant across the group.

Table 5. Length of Participation and Key Determinants.

\begin{tabular}{cccccc}
\hline & & N & Mean & Std. Dev. & Sig. \\
\hline & 1-5 years & 45 & 3.9296 & 0.46938 & \\
Micro-Enterprise & 6-10 Years & 193 & 3.9767 & 0.48699 & \\
Performance & 11-15 Years & 139 & 3.9525 & 0.59278 & 0.491 \\
& 16 Years and Above & 73 & 4.0594 & 0.54671 & \\
& Total & 450 & 3.9779 & 0.52957 & \\
Micro-Enterprise & 1-5 years & 45 & 4.3111 & 0.29857 & \\
Sustainability & 6-10 Years & 193 & 4.3463 & 0.33243 & \\
& 11-15 Years & 139 & 4.2158 & 0.43704 & \multirow{2}{*}{0.002} \\
& 16 Years and Above & 73 & 4.4000 & 0.34400 & \\
\hline
\end{tabular}

Source: Author(s) own compilation.

As presented in Table 6, micro-enterprise performance and micro-enterprise sustainability were grouped, based on the number of training programs attended by participants. The $p$-value of ANOVA F-test for micro-enterprise performance was 0.002 and the $p$-value of ANOVA F-test for micro-enterprise sustainability was 0.000 , which showed that the mean differences in micro-enterprise performance and sustainability were statistically significant across the groups.

As presented in Table 7, micro-enterprise performance and micro-enterprise sustainability were grouped, based on the total amount of economic loans received by participants. The $p$-value of ANOVA F-test for micro-enterprise performance was 0.780, which showed that the differences in micro-enterprise performance across the groups were not statistically significant. Meanwhile, the $p$-value of ANOVA F-test for micro-enterprise sustainability was 0.047 , thus showed that the mean value for at least one group was significantly different than others.

\subsection{Impact on Micro-Enterprise Performance}

A partial correlation was performed to determine the relationship between the change in micro-enterprise performance with years of participation, total number of trainings received, number of center meetings or discussions attended, and the total amount of economic loans received; after controlling the effect of age, education, gainfully employed members, sources of income, and the number of years the micro-enterprise had been established (see Table 8). Findings revealed a significant positive correlation between the number of years of participation in development initiatives, 
and micro-enterprise performance. Findings also revealed a positive correlation between the total number of trainings received, total number of training hours, number of center meetings or discussions attended, and micro-enterprise performance. However, the associations were not statistically significant (at a 5 percent level of significance). Furthermore, there was also a significant positive correlation between the total amount of economic loans received, and micro-enterprise performance.

Table 6. Training and Key Determinants.

\begin{tabular}{cccccc}
\hline & & N & Mean & Std. Dev. & Sig. \\
\hline & Up to 2 Trainings & 50 & 3.7200 & 0.72017 & \\
& 3 to 4 Trainings & 152 & 3.9836 & 0.52801 & \\
Micro-Enterprise & 5 to 6 Trainings & 154 & 4.0022 & 0.48619 & \\
Performance & 7 to 8 Trainings & 20 & 3.9333 & 0.37619 & 0.002 \\
& More than 9 Training & 74 & 4.1023 & 0.45250 & \\
& Total & 450 & 3.9779 & 0.52957 & \\
Micro-Enterprise & Up to 2 Trainings & 50 & 3.9800 & 0.48637 & \\
Sustainability & 3 to 4 Trainings & 152 & 4.3031 & 0.34927 & \\
& 7 to 8 Trainings & 154 & 4.3656 & 0.30413 & \\
& More than 9 Training & 74 & 4.4122 & 0.24468 & 0.000 \\
\hline
\end{tabular}

Source: Author(s) own compilation.

Table 7. Loan Received and Key Determinants.

\begin{tabular}{cccccc}
\hline & & N & Mean & Std. Dev. & Sig. \\
\hline & Up to 10 k & 66 & 3.9545 & 0.63215 & \\
Micro-Enterprise & $11 \mathrm{k}$ to $20 \mathrm{k}$ & 195 & 3.9573 & 0.53422 & \\
Performance & 21 k to 30 k & 115 & 3.9986 & 0.48641 & \multirow{2}{*}{0.780} \\
& 31 k and Above & 74 & 4.0212 & 0.48680 & \\
& Total & 450 & 3.9779 & 0.52957 & \\
Micro-Enterprise & Up to 10 k & 66 & 4.2379 & 0.43841 & \\
Sustainability & 11 k to 20 k & 195 & 4.2872 & 0.37556 & \multirow{2}{*}{0.047} \\
& 21 k to 30 k & 115 & 4.3391 & 0.35385 & \\
& 31 k and Above & 74 & 4.3964 & 0.30683 & \\
\hline
\end{tabular}

Source: Author(s) own compilation.

Table 8. Partial Correlation.

\begin{tabular}{|c|c|c|c|c|c|c|c|}
\hline Variables & & MEP & Year & Training & Hours & MD & Loan \\
\hline MEP & $\begin{array}{l}\text { Correlation } \\
\text { Sig. (1-tailed) }\end{array}$ & & & & & & \\
\hline \multirow{2}{*}{ Year } & Correlation & 0.039 & & & & & \\
\hline & Sig. (1-tailed) & 0.204 & & & & & \\
\hline \multirow{2}{*}{ Training } & Correlation & 0.136 & 0.115 & & & & \\
\hline & Sig. (1-tailed) & 0.002 & 0.007 & & & & \\
\hline \multirow{2}{*}{ Hours } & Correlation & 0.104 & 0.110 & 0.779 & & & \\
\hline & Sig. (1-tailed) & 0.014 & 0.010 & 0.000 & & & \\
\hline \multirow{2}{*}{ MD } & Correlation & 0.063 & -0.293 & 0.326 & 0.261 & & \\
\hline & Sig. (1-tailed) & 0.091 & 0.000 & 0.000 & 0.000 & & \\
\hline \multirow{2}{*}{ Loan } & Correlation & 0.040 & -0.058 & 0.335 & 0.292 & 0.301 & \\
\hline & Sig. (1-tailed) & 0.203 & 0.109 & 0.000 & 0.000 & 0.000 & \\
\hline
\end{tabular}

Note: (a) MEP-Micro-Enterprise Performance; Years—Number of years; Training-Total amount of trainings received; Hours-Total number of training hours; MD—Number of Centre Meetings or Discussions attended; Loan-Total amount of economic loans received. (b) Control variables-age, education, gainfully employed members, sources of income, micro-enterprise established. Source: Author(s) own compilation. 
Regression analysis was used to examine the effect of participation in development initiatives on micro-enterprise performance. This study revealed that as per the Durbin-Watson statistic, a value of 1.630, which was less than 2, indicates the absence of autocorrelation. The Variance Inflation Factors (VIF) values for all variables were below 5 , indicating the absence of multicollinearity issues. Since the $p$-value from the ANOVA analysis was 0.048 , which was less than 0.05 , it indicated that at least one variable was used to model 'micro-enterprise performance'.

Given that the Kolmogorov-Smirnov test of normality of the residuals gained a $p$-value of 0.000 , which was less than 0.05 , failing to meet the assumption of normality. The unstandardized residual stem-and-leaf plot, showed the outliers were based on the unstandardized residual values. After removing 281 outliers, the $p$-value for the Kolmogorov-Smirnov test of normality was more than 0.05 , satisfying the assumption of normality. Table 9 presents the analysis of 169 respondents, in terms of standardized beta and $p$-values.

Table 9. Regression Coefficients.

\begin{tabular}{cccccccc}
\hline & \multicolumn{3}{c}{$\boldsymbol{N = 4 5 0}$} & & \multicolumn{2}{c}{$N=\mathbf{1 6 9}$} \\
\hline & Unst. Beta & Std. Error & Stan. Beta & Sig. & VIF & Stan. Beta & Sig. \\
\hline (Constant) & 3.630 & 0.243 & & 0.000 & & & 0.000 \\
Years & 0.007 & 0.011 & 0.062 & 0.488 & 3.599 & 0.161 & 0.117 \\
Training & 0.025 & 0.015 & 0.132 & 0.102 & 2.957 & 0.137 & 0.119 \\
Hours & 0.000 & 0.002 & -0.007 & 0.928 & 2.736 & 0.044 & 0.609 \\
MD & 0.001 & 0.002 & 0.045 & 0.498 & 2.037 & -0.273 & 0.000 \\
Loan & $-5.207 \times 10^{-7}$ & 0.000 & -0.011 & 0.837 & 1.299 & -0.009 & 0.869 \\
Age & 0.000 & 0.004 & -0.007 & 0.917 & 1.993 & 0.108 & 0.136 \\
Education & 0.019 & 0.009 & 0.130 & 0.027 & 1.586 & 0.575 & 0.000 \\
GEM & -0.017 & 0.026 & -0.035 & 0.527 & 1.422 & 0.057 & 0.375 \\
Sources of Income & -0.010 & 0.096 & -0.005 & 0.918 & 1.225 & -0.034 & 0.540 \\
Established & 0.007 & 0.010 & 0.055 & 0.501 & 2.999 & 0.206 & 0.026 \\
\hline
\end{tabular}

Note: (Dependent variable) Micro-Enterprise Performance. (Independent variables) Years-Number of years; Training-Total number of training hours; Hours-Total number of hours of training received; MD—Number of Centre Meetings or Discussions attended; Loan-Total amount of economic loan received; (Control Variables) Age, Education, GEM-Gainfully Employed Members, Sources of Income, Established-Micro-Enterprise Established (Years). Source: Author(s) own compilation.

After removing the outliers $(N=169)$, the $r^{2}$ value was 0.605 , which indicated that 60.5 percent of the variation in 'micro-enterprise performance' was explained by years of participation, total number of trainings received, total number of training hours, number of center meetings or discussions attended, total amount of economic loans received, respondents' age, education, number of gainfully employed members, sources of income, and the number of years the micro-enterprise had been established. Furthermore, the Durbin-Watson statistic of 0.134 was below 2, which indicated the absence of autocorrelation. The VIF values for all variables were below 5, indicating the absence of multicollinearity issues. Since the $p$-value from the ANOVA analysis was less than $0.001(N=169)$, it meant that at least one variable was used to model 'micro-enterprise performance'.

The findings revealed that the length of participation (number of years), total number of training programs attended, and the total number of training hours had a positive effect on micro-enterprise performance. However, the effects of the length of participation, total number of training programs attended, number of training hours, number of center meetings or discussions attended, and total amount of economic loans received, were not statistically significant, i.e., at a 5 percent level of significance. Even though the effects of some indicators were positive, the data did not provide enough evidence to conclude that participation in development programs improved the performance of micro-enterprises owned and managed by low-income households in Kelantan, Malaysia (Hypothesis 1).

As for the effect of the control variables, the findings revealed a positive and significant effect of education on micro-enterprise performance. This confirmed the previous assumption and expectation that micro-enterprises, owned and managed by educated micro-entrepreneurs, benefitted greatly from 
the expertise gained and developed from the development initiatives. The findings also revealed a positive and significant effect of micro-enterprise establishment on micro-enterprise performance. The study showed that the longer the firm stayed in business, the better the performance. Meanwhile, the effects of other control variables were mostly inconclusive (in terms of direction of the association and level of significance), across the two groups $(N=450$ and $N=169)$.

\subsection{Impact on Micro-Enterprise Sustainability}

A partial correlation was performed to determine the relationship between micro-enterprise sustainability on years of participation, total number of trainings received, number of center meetings or discussions attended, and total amount of economic loans received; after controlling the effects of age, education, gainfully employed members, sources of income, and the number of years the micro-enterprise had been established (see Table 10). Findings revealed a positive correlation between the number of participation years in development initiatives and micro-enterprise sustainability. Furthermore, a positive correlation was found between the total number of trainings received, total number of training hours, number of center meetings and discussions attended, total amount of economic loans received, and micro-enterprise performance. The associations however were not statistically significant (at a 5 percent level of significance).

Table 10. Partial Correlation.

\begin{tabular}{|c|c|c|c|c|c|c|c|}
\hline Variables & & MES & Year & Training & Hours & MD & Loan \\
\hline MES & $\begin{array}{l}\text { Correlation } \\
\text { Sig. (1-tailed) }\end{array}$ & & & & & & \\
\hline \multirow{2}{*}{ Year } & Correlation & 0.066 & & & & & \\
\hline & Sig. (1-tailed) & 0.081 & & & & & \\
\hline \multirow{2}{*}{ Training } & Correlation & 0.216 & 0.115 & & & & \\
\hline & Sig. (1-tailed) & 0.000 & 0.007 & & & & \\
\hline \multirow{2}{*}{ Hours } & Correlation & 0.120 & 0.110 & 0.779 & & & \\
\hline & Sig. (1-tailed) & 0.006 & 0.010 & 0.000 & & & \\
\hline \multirow{2}{*}{ MD } & Correlation & 0.239 & -0.293 & 0.326 & 0.261 & & \\
\hline & Sig. (1-tailed) & 0.000 & 0.000 & 0.000 & 0.000 & & \\
\hline \multirow{2}{*}{ Loan } & Correlation & 0.088 & -0.058 & 0.335 & 0.292 & 0.301 & \\
\hline & Sig. (1-tailed) & 0.032 & 0.109 & 0.000 & 0.000 & 0.000 & \\
\hline
\end{tabular}

Note: (a) MES-Micro-Enterprise Sustainability; Years-Number of years; Training-Total amount of trainings received; Hours-Total number of training hours; MD—Number of Centre Meetings or Discussions attended; Loan-Total amount of economic loan received. (b) Control variables-age, education, gainfully employed members, sources of income, micro-enterprise established. Source: Author(s) own compilation.

The $r^{2}$ value was 0.140 , which indicated that 14 percent of the variation in 'micro-enterprise sustainability' was explained by years of participation, total number of trainings received, total number of training hours, number of center meetings or discussions attended, total amount of economic loans received, respondents' age, education, number of gainfully employed members, sources of income, and the number of years the micro-enterprise had been established. Furthermore, the Durbin-Watson statistic of 1.921 was below 2, which indicated the absence of autocorrelation. The VIF values for all variables were below 5, indicating the absence of multicollinearity issues. Since the $p$-value from the ANOVA analysis was less than 0.001, it meant that at least one variable was used to model 'micro-enterprise sustainability'.

Given that the Kolmogorov-Smirnov test of normality of the residuals gained a $p$-value of 0.000 , which was less than 0.05 , thus failing to meet the assumption of normality. The unstandardized residual stem-and-leaf plot, showed the outliers were based on the unstandardized residual values. After removing 241 outliers, the $p$-value for Kolmogorov-Smirnov test of normality was 0.20 , which 
was more than 0.05 , thus satisfying the assumption of normality. Table 11 presents the analysis of 209 respondents, in terms of the standardized beta and $p$-values.

Table 11. Regression Coefficients.

\begin{tabular}{cccccccc}
\hline & \multicolumn{3}{c}{$N=\mathbf{4 5 0}$} & & \multicolumn{2}{c}{$N=\mathbf{2 0 9}$} \\
\hline Unst. Beta & Std. Error & Stan. Beta & Sig. & VIF & Stan. Beta & Sig. \\
\hline (Constant) & 4.034 & 0.161 & & 0.000 & & & 0.000 \\
Years & 0.018 & 0.007 & 0.212 & 0.012 & 3.599 & 0.142 & 0.105 \\
Training & 0.032 & 0.010 & 0.236 & 0.002 & 2.957 & 0.663 & 0.000 \\
Hours & -0.002 & 0.001 & -0.134 & 0.067 & 2.736 & -0.301 & 0.000 \\
MD & 0.005 & 0.001 & 0.289 & 0.000 & 2.037 & 0.739 & 0.000 \\
Loan & $-5.480 \times 10^{-7}$ & 0.000 & -0.016 & 0.744 & 1.299 & -0.077 & 0.093 \\
Age & -0.004 & 0.002 & -0.115 & 0.067 & 1.993 & -0.173 & 0.003 \\
Education & 0.014 & 0.006 & 0.137 & 0.014 & 1.586 & 0.431 & 0.000 \\
GEM & -0.005 & 0.017 & -0.015 & 0.776 & 1.422 & -0.173 & 0.000 \\
Sources of Income & 0.050 & 0.064 & 0.038 & 0.434 & 1.225 & 0.247 & 0.000 \\
Established & -0.006 & 0.007 & -0.070 & 0.363 & 2.999 & 0.261 & 0.000 \\
\hline
\end{tabular}

Note: (Dependent variable) Micro-Enterprise Sustainability. (Independent variables) Years-Number of years; Training-Total number of training hours; Hours—-Total number of hours of training received; MD—Number of Centre Meetings or Discussions attended; Loan-Total amount of economic loan received; (Control Variables) Age, Education, GEM-Gainfully Employed Members, Sources of Income, Established-Micro-Enterprise Established (Years). Source: Author(s) own compilation.

After removing the outliers $(N=209)$, the $r^{2}$ value was 0.660 , which indicated that 66 percent of the variation in 'micro-enterprise sustainability' was explained by years of participation, total number of trainings received, total number of training hours, number of center meetings or discussions attended, total amount of economic loans received, respondents' age, education, number of gainfully employed members, sources of income, and the number of years micro-enterprise had been established. As the Durbin-Watson statistic of 0.470 was below 2, it indicated the absence of autocorrelation. The VIF values for all variables were below 5 , indicating the absence of multicollinearity issues. Since the $p$-value from the ANOVA analysis was less than 0.001, it meant that at least one variable was used to model 'micro-enterprise sustainability'.

The findings revealed that the effect of the number of years of participation, total number of trainings received, and the number of center meetings and discussions attended by the respondents had a positive effect on the sustainability of micro-enterprises owned and managed by low-income households in Kelantan, Malaysia. Findings also noted that the effect of the number of training hours and total amount of economic loans received were not statistically significant at a 5 percent level of significance. Although the findings provided some evidence about the positive impact of the length of participation in development initiatives, the effect of economic loans on sustainability was inconclusive (Hypothesis 2). As for the effect of control variables, the findings revealed a positive and significant effect of entrepreneur's education on sustainability of micro-enterprises, owned and managed by low-income households in Kelantan, Malaysia. However, the effect of sources of income and the number of years the micro-enterprise had been established had a positive and significant effect, after removing the outliers $(N=169)$.

\section{Conclusions}

The objectives of development initiatives are to improve micro-enterprise income generating activities, to positively impact performance and sustainability. Findings of this study revealed that the effects of a few participation indicators, on the performance and sustainability of micro-enterprises owned and managed by micro-entrepreneurs who participated in various development initiatives, were positive. However, the findings were inconclusive on the effects of participation indicators that were not statistically significant. Therefore, this study concludes that the impact of any development 
initiatives depends on participants' abilities to pair the knowledge and skills gained from the enterprise development training programs with access to working capital, to take advantage of income generating opportunities. Inconclusive findings about the impact of development programs, indicates a lack of capacity among the participants to learn and adopt new skills, as well as identify and make use of available income generating opportunities. Findings of this study highlighted that access to working capital and one-size-fits-all training programs, may be ineffective in improving the performance and sustainability of micro-enterprises. Well-diversified and specialized training programs, and flexible financial services, focused on seasonal income generating activities, may be more relevant and effective in impacting performance and sustainability of micro-enterprises owned and managed by participants from low-income households in Kelantan, Malaysia. Lastly, this study recommends the formation of an effective monitoring and evaluation system, for the development organizations in Malaysia. Effective monitoring and evaluation systems will enable development organizations to assess the way low-income borrowers use their loans in income generating activities, and thus be able to repay the loans on time and to develop effective programs and policies to improve overall business performance. As for the limitations, the willingness of the business owners to participate in the interviews was a challenge. The business owners were also reluctant to give information about their business, as they thought the researchers would give it away. Future researchers should draw a sample from AIM, TEKUN, and LKIM in the entirety of Malaysia, to establish if location affects involvement in increasing the performance and sustainability of micro-enterprises.

Author Contributions: All authors contributed to the designing of this study, data analysis, and finalizing the paper.

Funding: This research was funded by the Ministry of Higher Education, Malaysia under the grant, entitled "Developing a Comprehensive Rural Entrepreneurship Model for Poverty Eradication (REMODE)" (R/NRGS/A01.00/00047A/006/2014/000149).

Conflicts of Interest: The authors declare no conflict of interest.

\section{References}

Act 49 of the Malaysia Fisheries Development Board Act. 1971. Available online: http://www.agc.gov.my/ agcportal/uploads/files / Publications/LOM/EN/Act\%2049\%20-\%20Lembaga\%20Kemajuan\%20Ikan\% 20Malaysia\%20Act\%201971.pdf (accessed on 24 August 2018).

Adekunle, Bamidele. 2011. Determinants of microenterprise performance in Nigeria. International Small Business Journal 29: 360-73. [CrossRef]

Al-Mamun, Abdullah, Sazali Abdul Wahab, and Chinnasamy Agamudai Malarvizhi. 2010. Impact of Amanah Ikhtiar Malaysia's microcredit schemes on microenterprise assets in Malaysia. International Research Journal of Finance and Economics 60: 145-54.

Al-Mamun, Abdullah, Chinnasamy Agamudai Nambhi Malarvizhi, Sayed Hussain, and Sazali Abdul Wahab. 2011. Examining the effect of participation in microcredit programs on assets owned by hardcore poor households in Malaysia. African Journal of Business Management 5: 9286-96.

Al-Mamun, Abdullah, Joseph Adaikalam, and Mohammad Nurul Huda Mazumder. 2012. Examining the effect of Amanah Ikhtiar Malaysia microcredit program on microenterprise assets in rural Malaysia. Asian Social Science 8: 272-80.

Al-Mamun, Abdullah, Noorshella Binti Che Nawi, Mohd Asrul Hery Bin Ibrahim, and Rajennd Muniady. 2018. Effect of economic vulnerability on competitive advantages, enterprise performance and sustainability. Social Science 7: 1-11. [CrossRef]

Anderson, Leigh C., Laura Locker, and Rachel Nugent. 2002. Microcredit, Social Capital and Common Pool Resources. World Development 30: 95-105. [CrossRef]

Bank Negara Malaysia. 2013. Circular on New Definitions of Small and Medium Enterprises in Malaysia. Available online: http:/ / www.bnm.gov.my / files/2013/sme_cir_028_1_new.pdf (accessed on 30 April 2018).

Chan, Sow, and Mazanah Abdul Ghani. 2011. The impact of microloans in vulnerable remote areas: Evidence from Malaysia. Asia Pacific Business Review 17: 45-66. [CrossRef] 
Clark, Delwyn N., and Heather Douglas. 2014. Micro-enterprise growth: Lessons from home-based business in New Zealand. Small Enterprise Research 21: 82-98. [CrossRef]

Danciu, Victor. 2013. The sustainable company: New challenges and strategies for more sustainability. Theoretical and Applied Economics 20: 7-26.

DOSM. 2016. Small and Medium Enterprise Gross Domestic Product (GDP) 2016. Available online: https:/ /www.dosm. gov.my/v1/index.php?r=column/cthemeByCat\&cat=159\&bul_id=YzI2NWE2U0tXS1VEdnFsWHpqM1Fudz09\& menu_id=TE5CRUZCblh4ZTZMODZlbmk2aWRRQT09 (accessed on 10 April 2018).

Dunn, Elisabeth. 2005. Impacts of Microcredit on Clients in Bosnia and Herzegovina. Available online: https:/ / www.microfinancegateway.org/sites/default/files/mfg-en-paper-impact-of-microcredit-onclients-in-bosnia-and-herzegovina-2005.pdf (accessed on 31 March 2018).

EPU. 2018. Incidence of Poverty by Ethnic Group, Strata and State, Malaysia, 1970-2016. Available online: http:/ / www.epu.gov.my/en/search/node/incidence\%20of\%20poverty (accessed on 14 April 2018).

Ferdousi, Farhana. 2015. Impact of microfinance on sustainable entrepreneurship development. Development Studies Research 2: 51-63. [CrossRef]

Gualandris, Jury, Ruggero Golini, and Matteo Kalchschmidt. 2014. Do supply management and global sourcing matter for firm sustainability performance? An international study. Supply Chain Management: An International Journal 19: 258-74. [CrossRef]

Heckman, James J. 2000. Policies to Foster Human Capital. Research in Economics 54: 3-56. [CrossRef]

Kessy, Severine, and Sylvia Temu. 2010. The Impact of Training on Performance of Micro and Small Enterprises Served by Microfinance Institutions in Tanzania. Research Journal of Business Management 4: 103-11. [CrossRef]

Krejcie, Robert V., and Daryle W. Morgan. 1970. Determining sample size for research activities. Educational and Psychological Measurement 30: 607-10. [CrossRef]

LKIM. 2018. LKIM Schemes Program. Available online: http://www.lkim.gov.my/pembangunan-masyarakat-danpertubuhan-nelayan/ (accessed on 10 April 2018).

Montgomery, Heather, and John Weiss. 2011. Can Commercially-oriented Microfinance Help Meet the Millennium Development Goals? Evidence from Pakistan. World Development 39: 87-109. [CrossRef]

Muniady, Rajennd, Abdullah Al Mamun, Mohd. Rosli Mohamad, P. Yukthamarani Permarupan, and Noor Raihani Binti Zainol. 2015. The effect of cognitive and relational social capital on structural social capital and Microenterprise performance. SAGE Open 5: 1-9. [CrossRef]

Panda, Debadutta Kumar. 2009. Participation in the group based microfinance and its impacts on rural households: A quasi-experimental evidence from the Indian state. Global Journal of Finance and Management 1: 171-83.

Raderbauer, Marita. 2011. Strategic Sustainability-Strategic implementation of Sustainable Business practice in Viennese Accommodation. Master thesis, University of Exeter, Devon, UK.

Raymond, Louis, Marie Marchand, Louise Cadieux, and François Labelle. 2013. Dimension of small business performance from the owner-manager's perspective: A re-conceptualization and empirical validation. Entrepreneurship \& Regional Development 25: 468-99.

Rosenberg, Richard. 2010. Does Microfinance Really Help the Poor People? CGAP Focus Note. Available online: http:/ / www.cgap.org/publications / does-microcredit-really-help-poor-people (accessed on 31 March 2018).

Seibel, Hans Dieter. 1996. Coping with Scarcity: Microenterprise Strategies in Nigeria. Available online: https: / / www.hf.uni-koeln.de/data/eso/File/seibel/ElFo70.pdf (accessed on 23 February 2018).

SME Annual Report. 2015. Small and Medium Enterprise Annual Report 2015. Available online: http:/ / www. smecorp.gov.my/index.php/en/sme-annual-report-2015-16 (accessed on 15 April 2018).

Ssendi, Lucy, and Alistair R. Anderson. 2009. Tanzanian Micro Enterprises and Micro Finance. The Journal of Entrepreneurship 18: 1-19. [CrossRef]

Streletzki, Jan-Georg, and Reinhard Schulte. 2013. Start-up teams and venture capital exit performance in Germany: Venture capital firms are not selecting on the right criteria. Journal of Small Business E Entrepreneurship 26: 601-22.

Sutoro, Ann Dunham. 1990. KUPEDES Development Impacts Survey: Briefing Booklet; Central Jakarta: Planning, Research and Development Department, BRI.

Swain, Ranjula Bali, and Adel Varghese. 2009. Does Self Help Group Participation Lead to Asset Creation? World Development 37: 1674-82. [CrossRef] 
Trustees (Incorporation) Act. 1952. Available online: http://www.agc.gov.my/agcportal/uploads/files/ Publications/LOM/EN/Act\%20258\%20-\%20Trustees\%20(Incorporation)\%20Act\%201952.pdf (accessed on 24 August 2018).

Uotila, Antti. 2005. Livelihood Impact of Microfinance Access for the Poor: The Case of Vision FINCA Rwanda. MPhil Thesis, The University of Guelph, Guelph, ON, Canada.

World Bank. 2008. Finance for All: Policies and Pitfalls in Expanding Access. Washington: World Bank Policy Research Report.

(c)

(C) 2018 by the authors. Licensee MDPI, Basel, Switzerland. This article is an open access article distributed under the terms and conditions of the Creative Commons Attribution (CC BY) license (http://creativecommons.org/licenses/by/4.0/). 